\title{
Partnerstwo innowacyjne - komentarz do artykułu 31 Dyrektywy 2014/24/UE
}

\section{Wprowadzenie}

Wspieranie innowacji jest jednym z priorytetów polityki Unii Europejskiej (UE), wyrażonym m.in. w dokumentach strategicznych, w tym w Strategii na rzecz inteligentnego i zrównoważonego rozwoju sprzyjającego włączeniu społecznemu „Europa 2020"1. Innowacje, w tym ekoinnowacje i innowacje społeczne, uznane przez UE za jeden z głównych motorów przyszłego wzrostu, stanowią centralny punkt przywołanej strategii. Dla dokumentów strategicznych poza wyraźnym wskazaniem zamierzonych celów, charakterystyczne jest również określenie narzędzi mających je urzeczywistnić. Komisja Europejska w strategii „Europa 2020 " w tym zakresie proponuje m.in. szerokie wykorzystanie zamówień publicznych. Postulat ten należy odczytywać, po pierwsze, jako impuls do częstszego wykorzystywania instrumentów przewidzianych $\mathrm{w}$ dyrektywie 2004/18/UE² przez poszczególne instytucje zamawiające, a po drugie, jako bodziec do wprowadzenia nowych regulacji pozwalających na jeszcze szersze wspieranie tejże polityki.

${ }^{1}$ Komunikat Komisji Europejskiej z dnia 3 III 2010 r. Europa 2020 - Strategia na rzecz inteligentnego i zrównoważonego rozwoju sprzyjającego włączeniu społecznemu, KOM (2010) 2020 wersja ostateczna, dalej „Europa 2020”.

${ }^{2}$ Dyrektywa Parlamentu Europejskiego i Rady 2004/18/WE z dnia 31 III 2004 r. w sprawie koordynacji procedur udzielania zamówień publicznych na roboty budowlane, dostawy i usługi (Dz.Urz. UE L z 2014 r. nr 134). 
Nowe rozwiązania normatywne zostały przewidziane w dyrektywie 2014/24/UE³ , w której prawodawca unijny skonkretyzował również cele wyrażone w strategii "Europa 2020". W motywie 47 preambuły wskazano, że "zakup innowacyjnych produktów, robót budowlanych i usług odgrywa kluczową rolę w poprawie skuteczności i jakości usług publicznych, przyczyniając się przy tym do rozwiązywania poważnych problemów społecznych. Pozwala także uzyskać optymalną relację jakości do wielkości zainwestowanych środków publicznych, jak również szersze korzyści gospodarcze, środowiskowe i społeczne pod względem generowania nowych pomysłów, przełożenia ich na produkty i usługi innowacyjne, wspierając w ten sposób trwały wzrost gospodarczy".

W dyrektywie 2014/24/UE przyjęto wiele rozwiązań mających sprzyjać nabywaniu innowacyjnych produktów, usług lub robót budowlanych ${ }^{4}$. Szczególnym mechanizmem prawnym wykreowanym na potrzeby wspierania innowacji jest nowy tryb udzielania zamówień publicznych, przewidziany w art. 31 dyrektywy 2014/24/UE. Stanowi on uzupełnienie dotychczas przewidzianych procedur udzielania zamówień: procedury otwartej i ograniczonej, dialogu konkurencyjnego i procedury konkurencyjnej z negocjacjami. Ostatnia z wymienionych procedur stanowi szkielet, na którym oparto nowy tryb udzielania zamówień.

Podstawowe wytyczne dotyczace przebiegu postępowania w trybie partnerstwa innowacyjnego zawiera komentowany art. 31 dyrektywy 2014/24/UE, należy jednak pamiętać, że również do niego zastosowanie znajdują pozostałe przepisy tego aktu, w tym m.in. dotyczące publikacji ogłoszeń, kryteriów udzielenia zamówienia czy modyfikacji umów.

\section{Cel wprowadzenia trybu partnerstwa innowacyjnego}

Prezentując motywy skłaniające prawodawcę unijnego do wykreowania nowej procedury udzielania zamówień, należy zauważyć dwie kwestie. Pierwsza nie została w dyrektywie 2014/24/UE ukazana w sposób

${ }^{3}$ Dyrektywa Parlamentu Europejskiego i Rady 2014/24/UE z dnia 26 II 2014 r. w sprawie zamówień publicznych, uchylająca dyrektywę 2004/18/WE (Dz.Urz. UE L z 2004 r. nr 94/65), dalej „dyrektywa 2014/24/UE”.

${ }^{4}$ M. Blay, The Strategic Use of Public Procurement in Support of Innovation, "European Procurement \& Public Private Partnership Law Review" 2014, vol. 9, iss. 1, s. 3-11; J. Pożarowska, Instrumenty umożliwiające wsparcie rozwoju innowacji, w: Zamówienia publiczne w Unii Europejskiej po modernizacji - nowe unijne dyrektywy koordynujace procedury udzielania zamówień publicznych, pod red. M. Olejarz, Warszawa 2014, s. 145-161. 
szeroki, a dotyczy kształtowania rynku unijnego w zgodzie z przyjętymi, m.in. w dokumentach strategicznych, kierunkami rozwoju.

Zwiększenie innowacyjności gospodarki UE ma pozwolić na zagospodarowanie dotychczas niewykorzystywanych zasobów i w rezultacie na uzyskanie przewagi gospodarczej. Przyjęcie innowacji za jeden z głównych bodźców rozwoju UE oraz krajów członkowskich oparte jest na badaniach przedstawicieli nauk ekonomicznych, zapoczątkowanych przez J.A. Schumpetera ${ }^{5}$. Podstawą twierdzeń tego autora była teza, że innowatorem jest przedsiębiorca. Pozostaje ona w zgodzie z wartościami gospodarki rynkowej, wyrażonymi m.in. w art. 127 Traktatu o funkcjonowaniu Unii Europejskiej ${ }^{6}$ oraz art. 3 i 4 Traktatu o Unii Europejskiej ${ }^{7}$. Dlatego działania UE oraz państw członkowskich zasadniczo polegają na wspieraniu innowacji, w tym poprzez ich kreowanie przy wykorzystaniu instrumentów zamówień publicznych ${ }^{8}$. W związku z decentralizacja procesów zakupowych oddziaływanie UE na rynek instrumentami zamówieniowymi ma charakter pośredni, gdyż nakierowane jest na instytucje zamawiające, które następnie moga podejmować działania kształtujące postawy podmiotów zewnętrznych, wykonawców. Postawa zakupowa podmiotów publicznych może nie tylko tworzyć popyt na innowacyjne rozwiązania, ale również wpływać na ich dalszą pozapubliczną komercjalizację .

Powyższe implikuje drugą okoliczność stanowiącą motywację wprowadzenia nowej procedury udzielania zamówień, którą jest ułatwienie zamawiającym podejmowania działań zakupowych zmierzających do wspierania innowacji. Celem wprowadzenia regulacji dotyczących partnerstwa innowacyjnego jest umożliwienie zamawiającym zawiązania trwałej współpracy zmierzającej do realizacji inwestycji o charakterze innowacyjnym. Jego zastosowanie prowadzić ma zarówno do opracowania, jak i nabycia nowego, innowacyjnego produktu, usługi lub robót budowlanych. $W$ tym zakresie proces ten jest podobny do znanej w zamówieniach publicznych formuły nabywania robót

${ }^{5}$ J.A. Schumpeter, Teoria rozwoju gospodarczego, Warszawa 1960.

${ }^{6}$ Dz.Urz. UE C z 2012 r. nr 326.

${ }^{7}$ Dz.Urz. UE C z 2012 r. nr 326.

${ }^{8} \mathrm{~K}$. Różowicz, Ekoinnowacyjnośćjako element strategii biznesowej MŚP wzmacniajacy ich konkurencyjność na rynku zamówień publicznych, w: Państwo a gospodarka. Prawna regulacja podejmowania i prowadzenia działalności gospodarczej, pod red. H. Nowickiego, P. Nowickiego, W. Szwajdlera, Toruń 2014, s. 145-159.

${ }_{9}^{9}$ M. Porter, The Competitive Advantage of Nations, London-Basingstoke 1990. 
budowlanych w systemie „zaprojektuj i wybuduj” (Design \& Build) ${ }^{10}$. Przyczyny wprowadzenia tego trybu zostały w sposób szczegółowy wskazane w motywie 49 preambuły do wzmiankowanego aktu prawnego, zgodnie z którym: „Gdy dostępne na rynku rozwiązania nie mogą zaspokoić potrzeby opracowania innowacyjnego produktu lub usługi, lub innowacyjnych robót budowlanych oraz późniejszego zakupu wynikających dostaw, usług lub robót budowlanych, instytucje zamawiające powinny mieć dostęp do szczególnej procedury udzielania zamówień $\mathrm{w}$ odniesieniu do zamówień wchodzących w zakres stosowania niniejszej dyrektywy. Ta szczególna procedura powinna umożliwić instytucjom zamawiającym ustanowienie długotrwałego partnerstwa innowacyjnego w celu opracowania, a następnie zakupu nowego, innowacyjnego produktu, usługi lub robót budowlanych, pod warunkiem że taki innowacyjny produkt, usługa lub roboty budowlane mogą być wykonane zgodnie z ustalonymi poziomami wydajności i kosztami, bez konieczności przeprowadzania odrębnego postępowania o udzielenie zamówienia dla ich zakupu. [...]. Bez względu na to, czy projekty innowacyjne są bardzo duże czy mniejsze, partnerstwo innowacyjne powinno mieć taką strukturę, by mogło zapewnić niezbędny mechanizm popytowy, gdzie innowacyjne rozwiązania są opracowywane w odpowiedzi na zapotrzebowanie rynku (ang. market pull) bez wykluczania z rynku".

\section{Przedmiot partnerstwa}

Partnerstwo pomiędzy instytucją zamawiającą a wykonawcami zawierane jest $\mathrm{w}$ celu nabycia przez pierwszą $\mathrm{z}$ wymienionych innowacyjnego produktu, usługi lub roboty budowlanej. Centralnym punktem współpracy jest zatem kwalifikowany przedmiot transakcji, który musi posiadać cechę innowacyjności. Należy zatem podjąć próbę zdefiniowania przyjętego przez prawodawcę kwalifikatora.

Pojęcie innowacji pochodzi od łacińskiego: innovare, czyli tworzyć coś nowego ${ }^{11}$, stąd najczęstsza definicja innowacji podkreśla, że innowacja to wdrożenie nowego lub znacząco udoskonalonego produktu (wyrobu bądź usługi) albo procesu, nowej metody marketingowej lub

\footnotetext{
${ }^{10}$ P. Krzykowski, Zamówienia w systemie "Zaprojektuj i wybuduj”, LEX nr 128586.

${ }^{11}$ Słownik łacińsko-polski, http: //slowniki.seda.pl/polsko-lacinski.html (dostęp: $1 \mathrm{~V}$ 2016 r.).
} 
nowej metody organizacyjnej w praktyce gospodarczej, organizacji miejsca pracy lub stosunkach z otoczeniem ${ }^{12}$. W zbliżony sposób „innowacje" zostały zdefiniowane w art. 2 ust. 1 pkt 22 dyrektywy 2014/24/UE, w którym przyjęto, że oznaczają one „wdrażanie nowego lub znacznie udoskonalonego produktu, usługi lub procesu, w tym między innymi procesów produkcji, budowy lub konstrukcji, nowej metody marketingowej lub nowej metody organizacyjnej w działalności przedsiębiorczej, organizowaniu pracy, lub relacjach zewnętrznych m.in. po to, by pomóc rozwiązać wyzwania społeczne lub wspierać strategię «Europa 2020» na rzecz inteligentnego i zrównoważonego rozwoju sprzyjającego włączeniu społecznemu".

Pomiędzy pojęciem innowacji a partnerstwem innowacyjnym zachodzi więź. Należy jednak pamiętać, że zdefiniowane w art. 2 pkt 22 dyrektywy 2014/24/UE pojęcie odnosi się nie tylko do trybu udzielania zamówień będącego przedmiotem komentarza, ale również do innych uregulowań przewidzianych w tym akcie. Należy zatem za A. Panasiukiem wskazać, że „[...] intencją ustawodawcy unijnego było uznanie za innowacje wszelkich nowości wpływających na istniejący stan w danej dziedzinie. [...] Cele partnerstwa innowacyjnego, określone we wspomnianym art. 31 ust. 2, koncentrują się na kumulacji zysku w wyniku podjętych działań innowacyjnych. Tylko te działania, które przynoszą wymierne korzyści, będą mogły być uwzględniane w procedurach partnerstwa innowacyjnego. Z kolei w art. 2 pkt 22 ustawodawca europejski, definiując pojęcie innowacji, koncentruje się na celach, które mają zostać osiągnięte przez innowacyjne działania kontraktujących podmiotów, ze wskazaniem szczególnie na obszary działań społecznych oraz działań na rzecz zrównoważonego rozwoju. Wydaje się, że intencją było pogodzenie dwóch obszarów, na które zamówienia publiczne mogą wpływać i które mogą stymulować, to jest osiąganie wymiernych korzyści ekonomicznych oraz zaspokajanie pozaekonomicznych potrzeb społecznych. Jednak brak dostatecznej precyzji zapisów przedmiotowej dyrektywy prowadzi do niepewności prawnej w stosunku do warunków wykorzystania partnerstwa innowacyjnego, a przede wszystkim do trudności związanych z właściwym wdrożeniem tej instytucji do prawa krajowego"13.

${ }^{12}$ OECD/Eurostat, Podręcznik Oslo: zasady gromadzenia i interpretacji danych dotyczacych innowacji, Warszawa 2008.

${ }^{13}$ A. Panasiuk, Partnerstwo innowacyjne - pomoc w rozwoju innowacyjnej gospodarki?, „Kontrola Państwowa” 2015, nr 1, s. 160. 
Innowacyjny przedmiot współpracy partnerów jest jednocześnie jedną $z$ trzech przesłanek zastosowania nowo wykreowanego trybu udzielania zamówienia. Partnerstwo może zostać zawiązane, wyłącznie jeżeli tak określony przedmiot współpracy będzie przedmiotem transakcji wykazującej cechy zamówienia publicznego. Zatem zgodnie z art. 2 ust. 1 pkt 5 dyrektywy 2014/24/UE transakcja ta musi mieć charakter odpłaty, a jednocześnie być zawarta w formie umowy pisemnej pomiędzy co najmniej jednym wykonawcą a co najmniej jedną instytucją zamawiająca, zaś jej przedmiotem musi być wykonanie robót budowlanych, dostawa produktów lub świadczenie usług. Kolejną przesłanką jest zapotrzebowanie na produkt o charakterze innowacyjnym. Możliwość zastosowania nowej procedury nabycia dóbr i usług uzależniona jest zatem od niemożliwości zaspokojenia potrzeb zamawiającego poprzez zakup produktów, usług lub robót budowlanych już dostępnych na rynku. W świetle przyjętej przez prawodawcę unijnego definicji należy stwierdzić, że nabywane dobra lub usługi powinny być "nowe" lub "znacznie udoskonalone". Omawiany tryb nie znajdzie zastosowania w przypadku nabywania dostępnych rozwiązań, niewymagających dostosowania do indywidualnych potrzeb zamawiającego lub wymagających dostosowania w niewielkim stopniu. Powyższe ogranicza możliwości zastosowania omawianej procedury w przypadku nabywania dóbr charakteryzujących się jedynie niewielkim stopniem modyfikacji istniejących towarów i usług.

\section{Przebieg postępowania zmierzającego do zawiązania partnerstwa innowacyjnego}

Procedura zawiązania współpracy pomiędzy zamawiającym a partnerem albo partnerami ma charakter etapowy. Wyróżnić można w jej ramach dwa główne stadia: przygotowania zamówienia oraz jego udzielenia, które z kolei dzielą się na dalsze podetapy.

Swoistość procedury partnerstwa innowacyjnego wymaga podjęcia szczególnych czynności przygotowawczych. Zważając na treść przedstawionych powyżej przesłanek zastosowania tego trybu, zamawiający przed rozpoczęciem postępowania musi zbadać, czy jego potrzeby wymagają nabycia dóbr lub usług innowacyjnych, czy też mogą one zostać zaspokojone przez rozwiązania niewymagające indywidualnego dostosowania lub wymagające dostosowania w niewielkim stopniu. 
Tak sformułowane zastrzeżenie stawia przed instytucją zamawiająca konieczność przeprowadzenia uprzedniej i szczegółowej analizy rynku. Pozwoli to zamawiającemu zapobiec wszczynaniu postępowania, jeżeli istnieje na nim rozwiązanie spełniające jego oczekiwania lub istnieją powody pozwalające przyjąć, że w najbliższym czasie takowe powstanie.

Prawodawca unijny przewidział dodatkowo, że nabycie efektów współpracy innowacyjnej warunkowane jest posiadaniem przez nie odpowiedniego poziomu wydajności oraz nieprzekroczeniem maksymalnych kosztów uzgodnionych pomiędzy instytucją zamawiającą a uczestnikami. Zamawiający powinien zatem już w trakcie przygotowywania dokumentacji oszacować wartość zamówienia i określić wymogi wydajności przyszłej innowacyjnej inwestycji. Racjonalność procesu planowania inwestycji wymaga przyjęcia, że powinny być to wymagania minimalne, które nie uniemożliwiaja, a wręcz zachęcają do osiągnięcia jej większego poziomu.

Szacowanie wartości zamówienia dokonywane jest na podstawie art. 5 ust. 6 dyrektywy 2014/24/UE. Zgodnie z przywołanym przepisem zamawiający zobowiązany jest uwzględnić maksymalną szacunkową wartość bez VAT wszystkich działań badawczych i rozwojowych, które mają zostać przeprowadzone na każdym etapie planowanego partnerstwa, a także wszystkich dostaw, usług lub robót budowlanych, które mają zostać opracowane i zamówione na koniec planowanego partnerstwa. Jednocześnie dyrektywa 2014/24/UE w art. 31 ust. 7 wskazuje, że szacowana wartość dostaw, usług lub robót budowlanych powinna być proporcjonalna do wielkości inwestycji niezbędnej do ich opracowania.

Czynność szacowania wartości może powodować liczne komplikacje praktyczne, ponieważ czynności podejmowane są na wstępnym etapie, kiedy to zamawiający zna jedynie swoje potrzeby oraz rozwiązania istniejące na rynku. Ze względu na innowacyjny charakter przedmiotu zamówienia jego wartość może być trudna do oszacowania. Ponadto problemy w przewidzeniu przebiegu prac badawczo-rozwojowych, w tym konieczności lub braku konieczności przeprowadzenia części prac generujących koszty, mogą utrudniać precyzyjne oszacowanie wartości zamówienia. Instytucja zamawiająca powinna przeprowadzić te działania z zachowaniem należytej staranności, co nie gwarantuje tożsamości, ani nawet porównywalności oszacowanych kosztów z kosztem finalnym towaru lub usługi.

Efektem materialnym etapu przygotowawczego jest dokumentacja zamówienia. W przypadku procedury partnerstwa innowacyjnego 
będzie ona obejmowała niestandardowe kwestie, np. wykorzystania informacji poufnych czy własności intelektualnej.

W ramach etapu udzielenia zamówienia można wyróżnić sześć stadiów: publikację ogłoszenia, składanie wniosków, składanie ofert wstępnych, negocjacje, składanie ofert końcowych, wybór partnera lub partnerów.

Podstawą wszczęcia procedury partnerstwa innowacyjnego jest ogłoszenie o zamówieniu, zawierające informacje określone w części C załącznika V dyrektywy 2014/24/UE. Zamawiający w publikowanym ogłoszeniu określa swoje potrzeby nabywcze, które mają zostać zaspokojone przez wykonawców, oraz wymogi minimalne, jakie muszą spełniać oferty. Ponadto art. 31 ust. 6 dyrektywy 2014/24/UE nakłada na instytucje zamawiające obowiązek określenia w dokumentacji zamówienia rozwiązań mających zastosowanie do praw własności intelektualnej. Treść ogłoszenia powinna się charakteryzować precyzją, której stopień określa cel rozpowszechnienia informacji. Jest nim zapoznanie się potencjalnych wykonawców z charakterem inwestycji oraz oczekiwaniami zamawiającego względem wymaganego rozwiązania. Działanie zamawiającego ma umożliwić wykonawcom rzetelną ocenę opłacalności złożenia wniosku o dopuszczenie do udziału w postępowaniu.

Moment upowszechnienia ogłoszenia rozpoczyna kolejny podetap składania przez zainteresowane podmioty wniosków o dopuszczenie do udziału w postępowaniu. Minimalny termin, jaki musi wyznaczyć zamawiający na ich złożenie, wynosi 30 dni od daty wysłania ogłoszenia o zamówieniu. Gospodarz postępowania, określając termin, powinien uwzględnić w szczególności złożoność zamówienia i czas potrzebny na przygotowanie ofert i $\mathrm{w}$ razie zaistnienia potrzeby - wydłużyć go.

Każdy wykonawca musi przedstawić we wniosku informacje wymagane przez instytucję zamawiająca, które posłużą jej do przeprowadzenia procesu kwalifikacji podmiotowej. Podczas weryfikacji podmiotowej instytucje zamawiające stosują w szczególności kryteria dotyczące zdolności kandydatów w zakresie badań i rozwoju oraz opracowywania i wdrażania innowacyjnych rozwiązań. Przyjęcie takiego wyznacznika zdolności podmiotowej warunkowane jest charakterem inwestycji, w których istotniejsza od doświadczenia jest zdolność do realizowania innowacji. Stosowanie przywołanych kryteriów weryfikacji podmiotowej otwiera drogę współpracy również małym i nowo powstałym 
podmiotom budującym przewagę konkurencyjną opartą na stosowaniu innowacyjnych rozwiązań ${ }^{14}$, np. startupom.

W trakcie weryfikacji wniosków następuje selekcja wykonawców zapraszanych do udziału $\mathrm{w}$ dalszym podetapie postępowania. Zgodnie $z$ art. 65 ust. 1 i 2 dyrektywy 2014/24/UE instytucja zamawiająca może ograniczyć liczbę kandydatów do minimum trzech, każdorazowo jednak liczba zaproszonych kandydatów musi być wystarczająca, aby zapewnić prawdziwą konkurencję. Ograniczenie liczby kandydatów nie może nastąpić, jeśli liczba kwalifikujących się podmiotów jest równa wskazanej liczbie minimalnej. Jeżeli liczba kandydatów jest od niej mniejsza, instytucja zamawiająca może kontynuować postępowanie, zapraszając kandydatów posiadających wymagany potencjał.

Kolejne stadium rozpoczyna się od złożenia przez zakwalifikowane podmioty ofert wstępnych. Stanowią one podstawę do negocjacji z instytucją zamawiającą. Rokowania mogą dotyczyć wszystkich kwestii związanych z zamówieniem, np. jakości, klauzul handlowych, o ile nie stanowią one wymogów minimalnych oraz nie są kryteriami udzielenia zamówienia. Negocjacje są prowadzone z wszystkimi oferentami, którzy złożyli oferty wstępne spełniające minimalne wymagania określone w ogłoszeniu o zamówieniu.

Należy zauważyć, że negocjacji podlegają zarówno oferty wstępne, jak i oferty złożone w toku trwania tego etapu postępowania. Głównym celem negocjacji jest dostosowanie treści oferty do zapotrzebowania zamawiającego na zakup innowacyjnego produktu, usługi lub roboty budowlanej.

Negocjacje, zgodnie z art. 31 ust. 5 dyrektywy 2014/24/UE, moga zostać podzielone na kolejne subetapy, w celu ograniczenia liczby ofert będących przedmiotem negocjacji. Selekcja ofert odbywa się poprzez zastosowanie kryteriów uprzednio ustalonych przez zamawiającego. Możliwość skorzystania z uprawnienia do podziału negocjacji na subetapy warunkowana jest poinformowaniem o tym zainteresowanych podmiotów w ogłoszeniu o zamówieniu, w zaproszeniu do potwierdzenia zainteresowania lub $\mathrm{w}$ dokumentach zamówienia.

W art. 31 ust. 4 dyrektywy 2014/24/UE określone zostały reguły prowadzenia negocjacji. Odzwierciedlają one zasady prawa zamówień publicznych: równego traktowania wykonawców oraz ochrony konkurencji. W celu poszanowana wskazanych zasad instytucje zamawiające

${ }^{14}$ R. Grant, The Resource-based Theory of Competitive Advantage: Implications for Strategy Formulation, "California Management Review" 1991, s. 114. 
powinny prowadzić negocjacje w sposób przejrzysty, zapewniając przy tym równe i niedyskryminacyjne traktowanie wszystkich oferentów. Ponadto gospodarz postępowania został przez prawodawcę zobowiązany do informowania oferentów w formie pisemnej o wszelkich zmianach w specyfikacjach technicznych lub innych dokumentach zamówienia. Po wprowadzeniu zmian instytucje zamawiające zobowiązane są zapewnić oferentom wystarczająco dużo czasu na zmodyfikowanie i ponowne złożenie poprawionych ofert. Regulacja dyrektywy 2014/24/ UE nie precyzuje, jak długi powinien być to okres, stanowiąc, że należy rozpatrywać to indywidualnie w każdym przypadku. Instytucje zamawiające, kierując się zasadami prawa zamówień publicznych, powinny zapewnić wszystkim wykonawcom taki sam czas na złożenie poprawionych ofert.

W ścisłym związku z zasadami prawa zamówień publicznych pozostaje również regulacja przewidziana w art. 31 ust. 4 dyrektywy 2014/24/ UE, stanowiąca, że zamawiający nie może ujawniać pozostałym uczestnikom informacji poufnych przekazanych im przez kandydatów lub oferentów biorących udział w negocjacjach bez ich zezwolenia. Zgoda taka nie może mieć formy ogólnego zezwolenia, ale musi być wyrażona $\mathrm{w}$ odniesieniu do planowanego przekazania określonych informacji. Oznacza to, iż ze zgody na odtajnienie informacji zastrzeżonych jako poufne powinno dokładnie wynikać, które z nich mogą zostać ujawnione.

Po zakończeniu negocjacji uczestnicy, którzy pozostali w postępowaniu, składają oferty ostateczne, które następnie są oceniane przez instytucję zamawiającą. Oferty finalne podlegają weryfikacji w zakresie spełniania wymogów minimalnych i zgodności z art. 56 ust. 1 dyrektywy 2014/24/UE. Wybór oferty albo ofert następuje na podstawie kryterium najlepszej relacji jakości do ceny (art. 67 ust. 2 dyrektywy 2014/24/UE).

\section{Zawarcie umowy $\mathrm{i}$ jej realizacja}

Z wybranym partnerem albo partnerami instytucja zamawiająca zawiera umowę określającą m.in. zasady dotyczące organizacji partnerstwa, poszczególne etapy współpracy oraz cele pośrednie, które powinny zostać zrealizowane przez partnerów. Ponadto umowa powinna regulować takie kwestie, jak warunki wcześniejszego rozwiązania umowy o partnerstwo czy możliwość ograniczenia liczby partnerów na poszczególnych etapach. W związku z nabywczym charakterem umowy 
o zamówienie publiczne kluczowymi elementami wymagającymi doprecyzowania $\mathrm{w}$ umowie są: wynagrodzenie należne partnerom oraz warunki produkcji i dostawy produktu, wykonanie usługi lub realizacja roboty budowlanej.

W przypadku zawarcia umowy z kilkoma partnerami instytucja zamawiająca nie może ujawnić pozostałym partnerom proponowanych rozwiązań ani innych informacji poufnych udzielanych przez jednego z partnerów, bez jego zgody. Zgoda ta nie może mieć formy ogólnego zezwolenia, ale musi być wyrażona w odniesieniu do planowanego przekazania określonych informacji.

Instytucja zamawiająca musi zapewnić, by struktura partnerstwa oraz w szczególności czas trwania i wartość poszczególnych etapów odzwierciedlały stopień innowacyjności proponowanego rozwiązania i kolejność działań badawczo-innowacyjnych niezbędnych do opracowania innowacyjnego rozwiązania niedostępnego jeszcze na rynku. W tym kontekście należy przypomnieć motyw 49 preambuły dyrektywy 2014/24/UE, zgodnie z którym "partnerstwo innowacyjne powinno mieć taką strukturę, by mogło zapewnić niezbędny mechanizm popytowy, gdzie innowacyjne rozwiązania są opracowywane w odpowiedzi na zapotrzebowanie rynku (ang. market pull), bez wykluczania z rynku".

Podobnie jak procedura zawiązywania partnerstwa, również realizacja zobowiązań umownych następuje etapami, które odpowiadają fazom procesu badawczo-innowacyjnego. Prawodawca podzielił etap wykonawczy na dwie fazy: prowadzenia prac badawczych i rozwojowych zmierzających do komercjalizacji ich wyników oraz udzielenia konkretnego zamówienia w zakresie finalnego wyniku procesu komercjalizacji.

W ramach etapu badawczo-rozwojowego wyznaczane sa przez podmiot publiczny cele pośrednie, realizowane przez wykonawców. Powyższe rozwiązanie ma stanowić impuls do efektywnego i wydajnego działania partnerów. Ponadto ustanowienie tychże celów ma pomóc instytucji zamawiającej w ocenie realności osiągnięcia finalnego celu partnerstwa. Realizacja każdego z etapów podlega ocenie instytucji zamawiającej, która opierając się na wyniku weryfikacji, może zakończyć partnerstwo innowacyjne lub, w przypadku partnerstwa innowacyjnego z kilkoma partnerami, zmniejszyć liczbę partnerów poprzez rozwiązanie poszczególnych umów. Warunkiem skorzystania z takiej możliwości jest poinformowanie o niej w dokumentach zamówienia oraz określenie jej warunków. 
Korelatem obowiązków partnerów jest obowiązek instytucji zamawiającej do wypłaty wynagrodzenia w odpowiednich ratach. Dyrektywa 2014/24/UE nie określa szczegółowo zasad wypłaty rat wynagrodzenia.

Zwieńczeniem współpracy jest zakup przez instytucję zamawiająca dostaw, usług lub robót budowlanych będących wynikiem procesu badawczo-rozwojowego. Nabycie tychże dóbr lub usług jest możliwe pod warunkiem odpowiadania przez nie poziomem wydajności i maksymalnym kosztom do wcześniej ustalonych pomiędzy stronami. Mierniki te powinny zostać wyraźnie uregulowane w umowie o partnerstwo, a wcześniej również wstępnie określone w przygotowywanej przez instytucję zamawiającą dokumentacji postępowania.

\section{Podsumowanie}

Wybór procedury udzielenia zamówienia ma istotne znaczenie dla możliwości optymalnego zaspokojenia potrzeb zamawiającego ${ }^{15}$ oraz realizacji szerszych celów ${ }^{16}$. Dyrektywa 2014/24/UE wprowadziła nowy tryb dostosowany do nabywania innowacyjnych produktów, usług i robót budowlanych. Procedura ta skupia w sobie elementy klasycznych zamówień publicznych oraz partnerstwa publiczno-prywatnego. Bezpośredniość współpracy, a także jej długotrwałość stanowią główne czynniki wyróżniające ten tryb. Powyższe implikuje zmianę charakteru współpracy, która z procesu typowo nabywczego zbliża się do partnerstwa stron popytowej oraz podażowej. Stan ten nie modyfikuje charakteru prawnego relacji łączącej strony i działania zamawiającego $\mathrm{w}$ interesie publicznym, ale jedynie wymaga większego kooperowania pomiędzy stronami $\mathrm{w}$ celu osiągnięcia finalnego sukcesu. $\mathrm{W}$ takim ujęciu partnerstwo innowacyjne nie jest typową procedurą udzielania zamówień publicznych zmierzających do możliwie najszybszego nabycia aktywów.

Zrekonstruowany, na podstawie regulacji dyrektywy 2014/24/UE, przebieg postępowania wykazuje dużą złożoność. Powyższe wiąże się z charakterem podejmowanej współpracy, zmierzającej do wytworzenia innowacyjnego produktu, co zasadniczo jest działaniem

${ }^{15}$ K. Różowicz, Tryby postępowania, w: K. Różowicz, N. Gazecka, Zamówienia publiczne na dostawy i ustugi IT. Wybrane zagadnienia praktyczne, Warszawa 2016, s. 34-35.

${ }^{16}$ K. Uttam, C. Le Lann Roos, Competitive Dialogue Procedure for Sustainable Public Procurement, "Journal of Cleaner Production" 2015, vol. 86, s. 403-416. 
skomplikowanym. Pozytywnie należy ocenić wieloetapowość postępowania, możliwość podejmowania negocjacji, a także podjęcia współpracy z kilkoma parterami jednocześnie. Ułatwi to realne prowadzenie postępowań w trybie partnerstwa innowacyjnego.

Artykuł 31 dyrektywy 2014/24/UE wprowadza nową regulację proceduralna, jednakże jej wykorzystanie w pełni zależy od woli instytucji zamawiających. Dotychczas wiele mechanizmów przewidzianych w aktach regulujących dział prawa zamówień publicznych było wykorzystywanych sporadycznie ${ }^{17}$.

Należy przypuszczać, że procedura ta, nawet przy pozytywnym przyjęciu jej przez zamawiających, nie będzie wykorzystywana tak często jak inne procedury, w tym pozostałe tryby o charakterze negocjacyjnym. Wynika to bezpośrednio z charakteru przedmiotu, który w ramach jej zastosowania może zostać nabyty. Opierając się na dotychczasowych doświadczeniach, można przyjąć, że partnerstwo innowacyjne znajdzie zastosowanie w zamówieniach udzielanych przez podmioty szczebla centralnego, przy realizacji inwestycji o znacznych wartościach, m.in. w zakresie świadczeń informatycznych (systemy z zakresu e-government), ekologicznych (np. pojazdy hybrydowe), energetycznych (np. odnawialna energia) czy budowlanych (np. energooszczędne budynki).

${ }^{17}$ H. Nowicki, System zamówień publicznych jako regulacja prawna kreująca innowacyjność, w: Nowe podejście do zamówień publicznych - zamówienia publiczne jako instrument zwiększania innowacyjności gospodarki i zrównoważonego rozwoju. Doświadczenia polskie i zagraniczne, cz. I, Referaty na IV Konferencję Naukowa, 20-21.06.2011 r. Kazimierz Dolny, pod red. J. Niczyporuka, J. Sadowego, M. Urbanka, Warszawa 2011, s. 111-118; PARP, Innowacyjne zamówienia publiczne w Polsce - ekspertyza, Warszawa 2011. 